\title{
Sistem Deteksi Kawasan Bebas Rokok Dengan Menggunakan Sensor MQ-7 Berbasis Raspberry PI
}

\author{
Asa Arya Sudarman ${ }^{1}$ Linawati $^{2}$, Ni Made Ary Esta Dewi Wirastuti ${ }^{3}$
}

\begin{abstract}
This paper proposes a smoke detection tool that will be used to find out who will smoke in the classroom environment on campus.Implementation of the system smoker detector using Raspberry PI, sensor, webcam and also motor servo. Sensor that been used on the System to detect smoke from the cigarette is MQ7, which is detect the ratio of Carbon Monocside (CO) on the smoke. If the system detecting the cigarette, camera of the system will be headed to source of the smoke, capture the subject and then send the photo into telegram through the API using wifi connection. After the university side will monitoring the system and handle the subject whom breaking the rules due to smoking in the campus area is not allowed. The result of the experiment is the system which designed for smoke detector can detect the source of smoke is going well and appropriate regard on the scenario and functionality design. From the results of the prototype, the prototype can detect the smoke that come from cigarettes according the location. The experiment on indoor area show the success level is get almost most value within 15 second and an average distance $300 \mathrm{~cm}$. For result above $400 \mathrm{~cm}$ get results below $50 \%$.
\end{abstract}

Intisari- Paper ini mengusulkan tentang sebuah alat deteksi asap yang akan digunakan untuk mengetahui siapakah orang yang akan merokok di lingkungan kelas pada kampus. Implementasi dari rancangan pemantauan sumber asap rokok menggunakan mikroprosesor Raspberry Pi, sensor, webcam dan motor servo. Sensor yang digunakan adalah sensor MQ-7 sebagai pendeteksi kadar karbon monoksida (CO) yang terkandung pada asap rokok. Jika terdeteksi asap rokok maka kamera webcam mengarah pada sumber asap dan meng-capture perokok tersebut serta mengirim gambarnya via Wi-fi dengan API Telegram. Nantinya pihak kampus dapat memantau dalam menangani mahasiswa dan civitas kampus yang melanggar aturan merokok di lingkungan kampus. Dari hasil pengujian prototipe pada ruangan tertutup menunjukkan bahwa rancangan ini dapat mendeteksi sumber asap rokok dan perokok berjalan dengan baik, sesuai kebutuhan sistem dengan persentase keberhasilan hampir mendekati nilai sempurna untuk hasil di dalam ruangan dengan kurun waktu 15 detik dan dalam jarak rata-rata 300 $\mathrm{cm}$ untuk hasil di atas $400 \mathrm{~cm}$ mendapatkan hasil di bawah $50 \%$.

Kata Kunci- Asap Rokok, Capture, Kampus, Sensor MQ-7, Telegram.

\section{PENDAHULUAN}

Kampus merupakan suatu lingkungan yang seharusnya bersih terhadap asap rokok. Namun, Saat ini masih banyak mahasiswa dan civitas kampus yang sering melanggar aturan tentang larangan merokok pada lingkungan kampus [1] . Bagi

\footnotetext{
${ }^{1}$ Mahasiswa Teknik Elektro, Universitas Udayana, Kampus Bukit Jimbaran, Badung, Bali 80361 Indonesia e-mail: asaaryasudarman@gmail.com

2, 3 Dosen,Jurusan Teknik Elektro Fakultas Teknik Universitas

Udayana, Jln. Jalan Kampus Bukit Jimbaran 80361 INDONESIA (telp: 0361-703315; fax: 0361-703315; e-mail: linawati@unud.ac.id,arydev_02@yahoo.com
}

mahasiswa dan civitas akademik yang tidak merokok, asap rokok selain dapatmenyebabkan gangguan kesehatan, juga dapat menyebabkan rasa tidak nyaman. Bagi Universltas Udayana tentu hal ini juga menjadi masalah, karena bertentangan dengan slogan kampus sehat dan slogan kampus tanpa asap rokok. Perlunya membuat perubahan dari sistem pengontrolan yang belum ada saat ini, dimana sistem ini dapat memantau perokok yang berada pada lingkungan kampus kepada warga kampus melalui sosial media, sehingga pihak kampus dapat memantau dalam menangani mahasiswa dan civitas kampus yang melanggar aturan merokok pada lingkungan kampus.

Dengan adanya masalah tersebut pada paper ini, diperlukannya sebuah sistem yang dapat mendeteksi perokok yang berada pada lingkungan kampus. Alat yang dibangun memanfaatkan sensor MQ- 7 dan webcam. Sensor MQ-7 akan digunakan sebagai pendeteksi asap rokok. Sensor dan webcam tersebut akan dikontrol menggunakan mikroprosesor yaitu Raspberry Pi. Apabila terdeteksi adanya asap rokok maka mikroprosesor akan mengaktitkan webcam. Webcam digunakan untuk meng-capture lokasi dimana terdeteksi asap rokok. Hasil dari capture akan diolah menjadi sebuah informasi yang nantinya akan dikirimkan pada Telegram tanpa memperhitungkan analisis citra kamera yang memiliki jangkauan yang relatif jauh dan luas.

Pada penelitian sebelumnya menjelaskan rancangan dan realisasi alat yang mampu mendeteksi asap rokok dan kebakaran menggunakan sensos SHT-II dan sensor MQ-7. Alat ini juga dirancang untuk memberi pemberitahuan berupa alarm pada saat terdeteksi asap rokok dan kebakaran, serta mengaktifkan sirkulator dan pewangi ruangan apabila terdeteksi asap rokok. Sedangkan apabila terjadi kebakaran atau asap rokok di atas rata-rata normal akan memberikan pesan kepada petugas melalui sms gateway yang digunakan untuk menertibkan pengunjung yang merokok atau melakukan pertolongan pertama pada saat terjadi kebakaran. [2][3][4][5] [13]

\section{METODE}

Pada penelitian dibuat suatu rancangan dari sistem pemantau menggunakan webcam yang terintegrasi dengan menggunakan motor servo sehingga dapat bergerak guna menambah variasi sudut pandang. Sistem pengendali piranti elektronik ini dapat dirancang menjadi suatu aplikasi yang dapat diakses menggunakan WEB GUI dengan bantuan Raspberry $\mathrm{Pi}$ modal Tipe $\mathrm{B}$ yang digunakan sebagai webserver.

Dari hasil pengujian didapat program live streaming webcam pada halaman aplikasi, pengedalian arah webcam melalui web, dan pengendalian kontrol on-off melalui piranti 
elektronik berupa lampu pijar melalui web yang memiliki tingkat keberhasilan $100 \%$ dari $10 \mathrm{kali}$ percobaan. [11]Jadi, dari hasil penelusuran pustaka di atas dapat dikembangkan dalam penelitian yang dilakukan oleh penulis dengan memperbesar jarak deteksi sensor MQ-7 yang semula jarak maksimal deteksi $100 \mathrm{~cm}$ menjadi $200 \mathrm{~cm}$. Serta pada sumber penelitian digunakan satu motor servo terhadap webcam variansudut hanya tiga titik, sedangkan penulis melakukan pengujian terhadap motor servo menggunakan 2 motor servo dengan sembilan varian sudut. Capture yang digunakan penulis berupa gambar yang di posting pada Telegram, sedangkan pada penelitian menggunakan live streaming, [7][8][9][10] serta penulis menarnbahkan sensor untuk mendeteksi lokasi keberadaan sumber asap rokok dan orang yang merokok.

Prototype yang dibangun pada paper ini adalah sebuah sistem pendeteksi asap rokok yang berbasis komunikasi Machine-to-Machine (M2M) pada ruangan bebas asap rokok. Proses ini dilakukan secara otomatis, yakni menggunakan sensor untuk mendeteksi asap rokok pada ruangan tersebut. Sensor yang digunakan pada paper ini adalah Sensor MQ-7 sebagai rokok pada ruangan tersebut. Sensor yang digunakan pada paper ini adalah Sensor MQ-7 sebagai sensor pendeteksi kandungan zat karbonmonoksida (CO), serta Webcam yang digunakan sebagai pengambilan gambar di lokasi terdeksinya asap rokok. Setiap respon yang terdeteksi oleh sensor dan capture gambar akan dibaca oleh mikroprosesor yaitu menggunakan Raspberry Pi tipe B. Gambar tersebut akan diolah menjadi sebuah informasi yang nantinya akan dikirimkan pada Telegram. Hambatan permukaan sensor Rs diperoleh melalui dipengaruhi sinyal output tegangan dari resistansi beban RL yang seri. Hubungan antara itu dijelaskan: Rs $\backslash R L=(V c-V R L) /$ VRL sinyal ketika sensor digeser dari udara bersih untuk karbon monoksida (CO), pengukuran sinyal dilakukan dalam waktu satu atau dua periode pemanasan lengkap (2,5 menit dari tegangan tinggi ke tegangan rendah). Lapisan sensitif dari MQ-7 komponen gas sensitif terbuat dari SnO2 dengan stabilitas, Jadi, ia memiliki stabilitas jangka panjang yang sangat baik.[13]

Karakteristik sensor MQ-7 tersebut dapat mendeteksi asap rokok dengan akurasi $100 \%$ pada jarak $10 \mathrm{~cm}$ sampai dengan $60 \mathrm{~cm}$ dengan respon time yang kurang dari 1 menit. Untuk jarak $80 \mathrm{~cm}$ akurasi sebesar $80 \%$ dan pada jarak yang besar dari $100 \mathrm{~cm}$ mendeteksi asap memiliki respon time yang dianggap kurang effisien sebesar 5 menit Standar Kondisi Bekerja $=$ Temperature $-20^{\circ} \mathrm{C} \pm 2^{\circ} \mathrm{C}$ Kelembapan $65 \% \pm 5 \%$ [12]

Berikut blok diagram sistem kerja alat:

Asa Arya Sudarman: Sistem Kawasan Bebas Rokok Dengan (...)

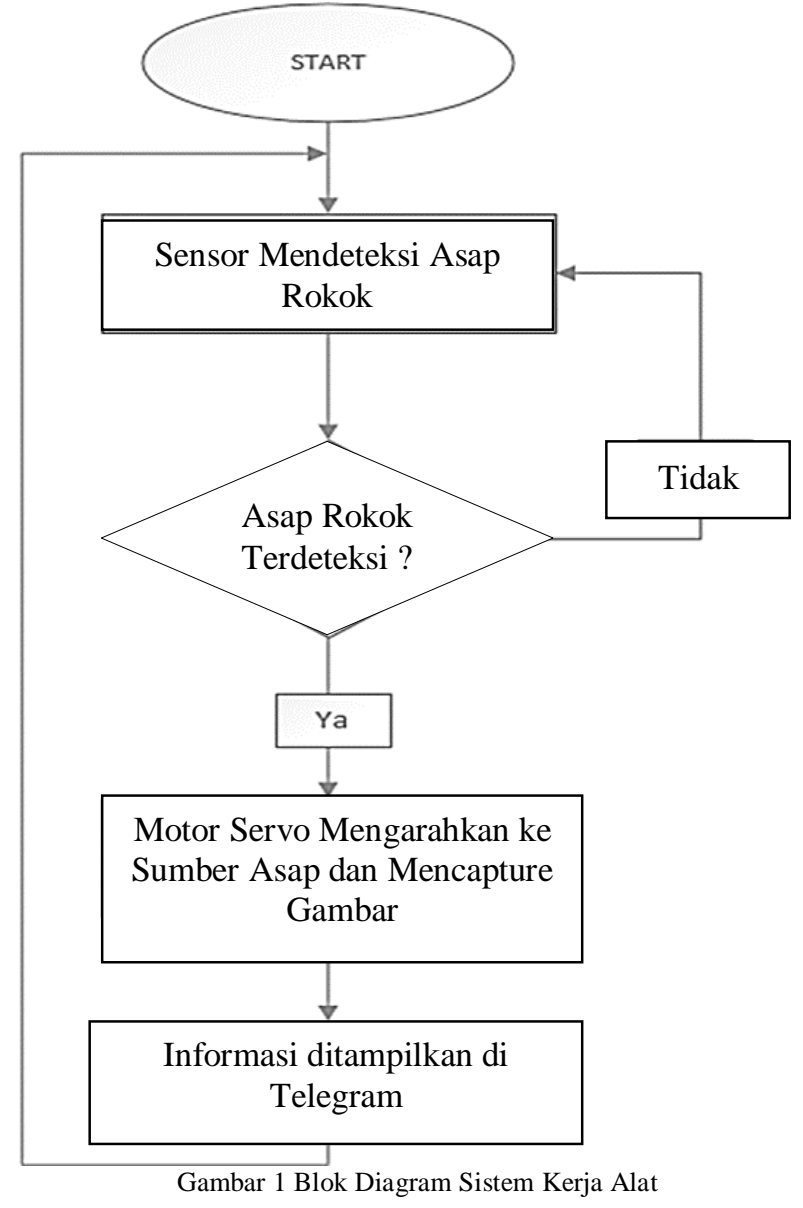

Berikut flowchart dari sistem:

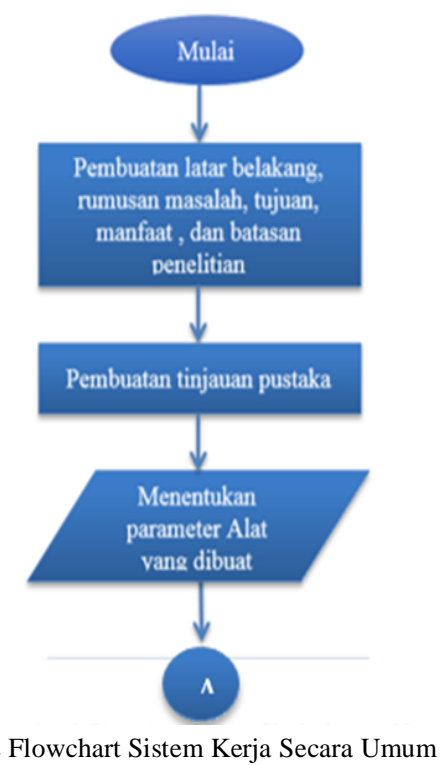

Gambar 2 Flowchart Sistem Kerja Secara Umum

Asa Arya Sudarman: Sistem Kawasan Bebas Rokok Dengan (...) 


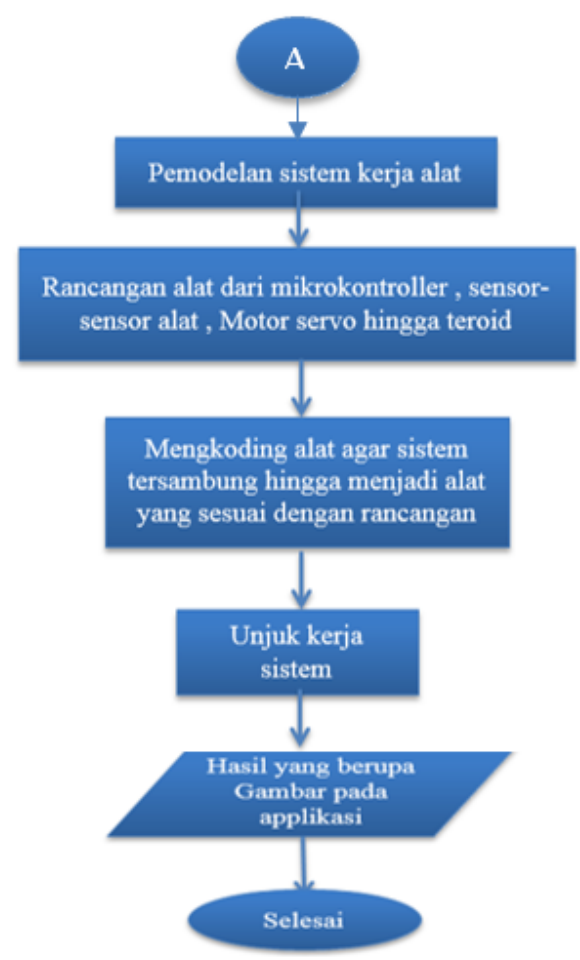

Gambar 3 Flowchart Lanjutan Sistem Kerja Secara Umum

\section{HASIL DAN PEMBAHASAN}

A. Analisis Jarak Deteksi Sensor

Pengujian prototype terhadap jarak yang dideteksi oleh sensor dilakukan pada lokasi tertutup. Setelah melakukan pengukuran terhadap jarak yang dapat dideteksi oleh sensor di dapatkan hasil sebagai berikut :

Tabel 1 PENGUKURAN JARAK DETEKSI SENSOR

\begin{tabular}{|c|c|c|c|c|c|}
\hline $\begin{array}{c}\text { Percobaan } \\
\text { Sensor }\end{array}$ & \multicolumn{5}{|c|}{ Jarak Sensor (cm) } \\
\cline { 2 - 6 } & $\mathbf{5 0}$ & $\mathbf{1 0 0}$ & $\mathbf{2 0 0}$ & $\mathbf{3 0 0}$ & $\mathbf{4 0 0}$ \\
\hline 1 & $\mathrm{~V}$ & $\mathrm{~V}$ & $\mathrm{~V}$ & $\mathrm{~V}$ & $\mathrm{X}$ \\
\hline 2 & $\mathrm{~V}$ & $\mathrm{~V}$ & $\mathrm{~V}$ & $\mathrm{~V}$ & $\mathrm{X}$ \\
\hline 3 & $\mathrm{~V}$ & $\mathrm{~V}$ & $\mathrm{~V}$ & $\mathrm{~V}$ & $\mathrm{~V}$ \\
\hline 4 & $\mathrm{~V}$ & $\mathrm{~V}$ & $\mathrm{~V}$ & $\mathrm{~V}$ & $\mathrm{X}$ \\
\hline 5 & $\mathrm{~V}$ & $\mathrm{~V}$ & $\mathrm{~V}$ & $\mathrm{~V}$ & $\mathrm{~V}$ \\
\hline
\end{tabular}

Keterangan :

$$
\begin{aligned}
& \mathrm{V}=\text { Terdeteksi asap rokok } \\
& \mathrm{X}=\text { Tidak terdeteksi asap rokok }
\end{aligned}
$$

Dari tabel tersebut didapatkan data jarak maksimal yang dapat dideteksi oleh sensor yang digunakan yaitu sensor MQ-7. Jadi, jarak maksimal rata-rata yang dapat dijangkau oleh sensor yaitu pada jarak $200 \mathrm{~cm}$.

Asa Arya Sudarman: Sistem Kawasan Bebas Rokok Dengan ....
B. Peletakan Sensor

Pengujian peletakan sensor dilakukan untuk mengetahui jumlah sensor yang dibutuhkan dalam pengujian sistem ini, berikut pengujian yang dilakukan:

\section{a. Empat Sensor}

Pada pengujian empat sensor dilakukan di empat titik berbeda. Berikut hasil gambar peletakan :

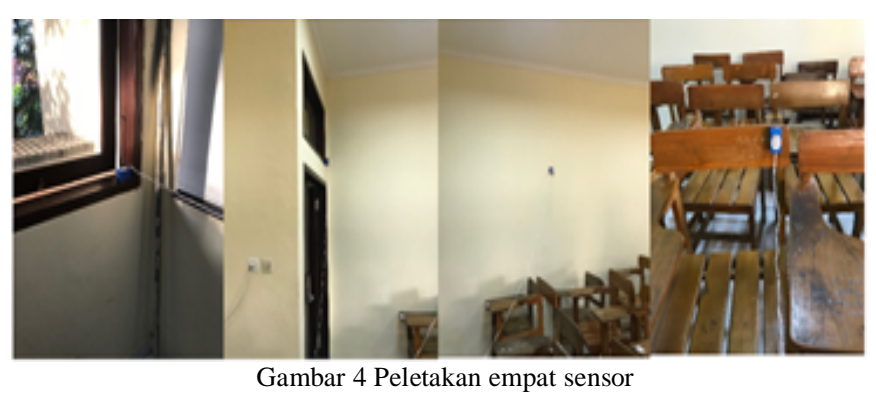

Dari hasil uji gambar diatas didapatkan hasil sebagai berikut:

Tabel 2 PENGUJIAN TITIK 1,2,3 DAN 47

\begin{tabular}{|c|c|c|c|c|}
\hline $\begin{array}{c}\text { Besar } \\
\text { Lokasi } \\
\text { Pengujian } \\
\text { (meter) }\end{array}$ & $\begin{array}{c}\text { Besar jarak } \\
\text { alat } \\
\text { Pengujian } \\
\text { (meter) }\end{array}$ & Variabel & Terdeteksi & $\begin{array}{c}\text { Waktu } \\
\text { Terdeteksi } \\
\text { (detik) }\end{array}$ \\
\hline $4 \times 4$ & $3 \times 3$ & $\begin{array}{c}\text { Ada perokok } \\
\text { antara titik a } \\
\text { dan b }\end{array}$ & Terdeteksi & 11 \\
\hline $4 \times 4$ & $3 \times 3$ & $\begin{array}{c}\text { Ada perokok } \\
\text { antara titik b } \\
\text { dan c }\end{array}$ & Terdeteksi & 13 \\
\hline $4 \times 4$ & $3 \times 3$ & $\begin{array}{c}\text { Ada perokok } \\
\text { antara titik c } \\
\text { dan d }\end{array}$ & Terdeteksi & 14 \\
\hline $4 \times 4$ & $3 \times 3$ & $\begin{array}{c}\text { Ada perokok } \\
\text { antara titik d } \\
\text { dan a }\end{array}$ & Terdeteksi & 13 \\
\hline
\end{tabular}

Berdasarkan hasil pengujian sensor di atas, terlihat bahwa lama waktu terdeteksi dipengaruhi oleh sensitivitas sensor mq-7 itu sendiri karena sensor tersebut bisa di atur sensitifitasnya langsung pada alatnya. Terlihat pada tabel di atas, setiap sensor memiliki range waktu terdeteksi berbedabeda dengan sensor yang lainnya. Dan table di atas menunjukan waktu terdeteksinya alat dari asap menyala hingga masuk pada applikasi telegram.

\section{b. Lima Sensor}

Pada pengujian lima sensor ini dilakukan peletakan di lima titik berbeda. Berikut hasil gambar peletakan:

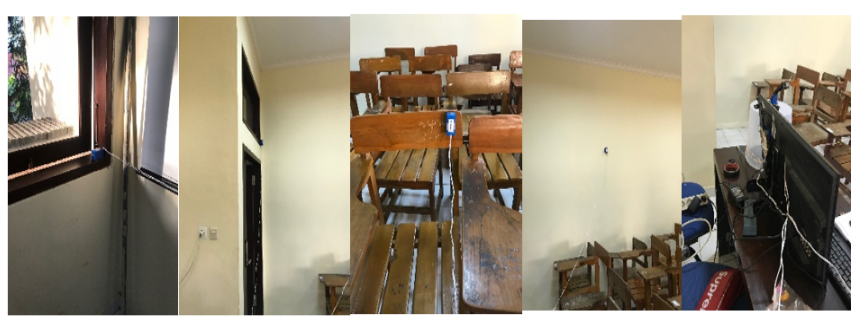

Gambar 5 Peletakan lima sensor

p-ISSN:1693 - 2951; e-ISSN: 2503-2372

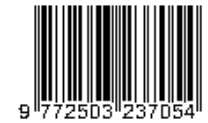


Dari hasil uji gambar diatas didapatkan hasil sebagai berikut: Tabel 1 PENGUJIAN TITIK 1,2,3,4 DAN 5

\begin{tabular}{|c|c|c|c|c|}
\hline $\begin{array}{c}\text { Besar } \\
\text { Lokasi } \\
\text { Pengujian } \\
\text { (meter) }\end{array}$ & $\begin{array}{c}\text { BesarFarak } \\
\text { alat } \\
\text { Pengujian } \\
\text { (meter) }\end{array}$ & Variabel & Terdeteksi & $\begin{array}{c}\text { Waktu } \\
\text { Terdeteksi } \\
\text { (detik) }\end{array}$ \\
\hline 4 X 4 & $3 \times 3$ & $\begin{array}{c}\text { Ada perokok } \\
\text { antara titik a } \\
\text { dan b }\end{array}$ & Terdeteksi & 11 \\
\hline 4 X 4 & $3 \times 3$ & $\begin{array}{c}\text { Ada perokok } \\
\text { antara titik b } \\
\text { dan c }\end{array}$ & Terdeteksi & 13 \\
\hline 4 X 4 & $3 \times 3$ & $\begin{array}{c}\text { Ada perokok } \\
\text { antara titik c } \\
\text { dan d }\end{array}$ & Terdeteksi & 14 \\
\hline 4 X 4 & $3 \times 3$ & $\begin{array}{c}\text { Ada perokok } \\
\text { antara titik d } \\
\text { dan e }\end{array}$ & Terdeteksi & 13 \\
\hline 4 X 4 & $2 \times 2.5$ & $\begin{array}{c}\text { Ada perokok } \\
\text { antara titik e } \\
\text { dan a }\end{array}$ & Terdeteksi & 7 \\
\hline
\end{tabular}

Berdasarkan hasil pengujian sensor di atas, terlihat bahwa lama waktu terdeteksi dipengaruhi oleh sensitivitas sensor mq-7 itu sendiri karena sensor tersebut bisa di atur sensitifitasnya langsung pada alatnya. Terlihat pada tabel di atas, setiap sensor memiliki range waktu terdeteksi berbedabeda dengan sensor yang lainnya. Dan table di atas menunjukan waktu terdeteksinya alat dari asap menyala hingga masuk pada applikasi telegram.

C. Analisis pengujian webcam dan motor servo untuk mengetahui akurasi sudut kamera

Pengujian ini dilakukan untuk mengetahui posisi sudut motor servo yang digunakan. Pada motor servo $180^{\circ}$ hanya dua arah guna dari motor servo ini untuk menambah variasi sudut pandang hasil capture pada Webcam.

Tabel 4 PENGUJIAN POSISI MOTOR SERVO

\begin{tabular}{|c|c|c|}
\hline $\begin{array}{c}\text { Posisi Motor } \\
\text { Servo }\end{array}$ & Sensor Deteksi & Hasil \\
\hline 0 & A dan C & Sesuai posisi yang direncanakan \\
\hline 1 & A & Sesuai posisi yang direncanakan \\
\hline 2 & A dan B & Sesuai posisi yang direncanakan \\
\hline 3 & B & Sesuai posisi yang direncanakan \\
\hline $4 /-4$ & B dan D & Sesuai posisi yang direncanakan \\
\hline-1 & C & Sesuai posisi yang direncanakan \\
\hline-2 & C dan D & Sesuai posisi yang direncanakan \\
\hline-3 & D & Sesuai posisi yang direncanakan \\
\hline Tengah & E & Sesuai posisi yang direncanakan \\
\hline
\end{tabular}

Berdasarkan tabel di atas dapat disimpulkan bahwa dari kesembilan posisi yang telah diujikan pada kedua motor servo yang digunakan menghasilkan posisi yang sesuai dengan skenario yang sudah dirancang.

\section{Analisis Pengujian Fungsi}

Pada pengujian ini dilakukan untuk mengetahui apakah perbedaan lokasi tertutup dan terbuka berpengaruh pada deteksi asap rokok terhadap sensor. Sensor yang digunakan pada pengujian ini menggunakan lima buah sensor yang telah diujikan sesuai dengan fungsionalitas yang diharapkan. Pengujian ini ditambahkan akurasi pendeteksian wajah perokok yang di-capture oleh kamera.
E. Hasil Pengujian Keakuratan di ruangan Tertutup

Berikut hasil dari capture kamera yang jelas pada wajah.

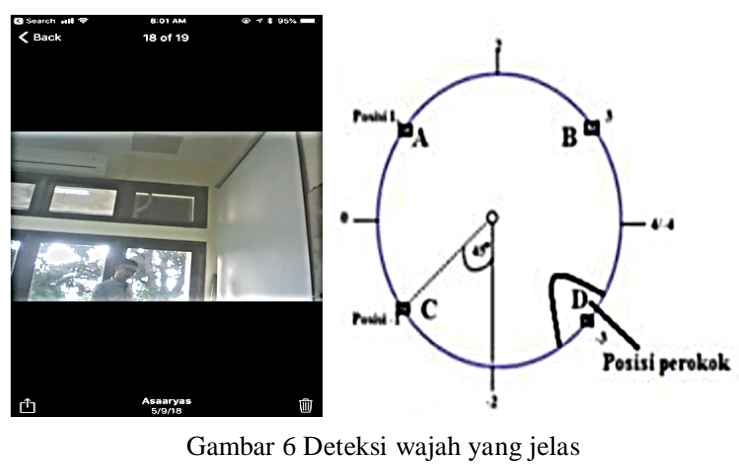

Hasil pengujian pada ruangan tertutup yang telah diakukan dapat dilihat pada tabel di bawah ini:

Table 1.5 Pengujian Pada ruang tertutup

\begin{tabular}{|c|c|c|c|c|}
\hline $\begin{array}{c}\text { Titik } \\
\text { Pengujian }\end{array}$ & $\begin{array}{c}\text { Terdeteksi } \\
\text { Sensor }\end{array}$ & $\begin{array}{c}\text { Sesuai } \\
\text { Sudut }\end{array}$ & $\begin{array}{c}\text { Pesan } \\
\text { Terkirim }\end{array}$ & $\begin{array}{c}\text { Foto } \\
\text { (Wajah) }\end{array}$ \\
\hline Titik A & Ya & Ya & Ya & Jelas \\
\hline Titik B & Ya & Ya & Ya & Jelas \\
\hline Titik C & Ya & Ya & Ya & Jelas \\
\hline Titik D & Ya & Ya & Ya & Jelas \\
\hline Titik E & Ya & Ya & Ya & Jelas \\
\hline Titik A dan B & Ya & Ya & Ya & Jelas \\
\hline Titik B dan C & Ya & Ya & Ya & Jelas \\
\hline Titik C dan D & Ya & Ya & Ya & Jelas \\
\hline Titik D dan E & Ya & Ya & Ya & Jelas \\
\hline Titik E dan A & Ya & Ya & Ya & Jelas \\
\hline
\end{tabular}

Berdasarkan hasil tabel pengujian di atas terlihat bahwa keakuratan alat dalam mendeteksi perokok dalam ruangan tertutup sangat baik. Terlihat hampir di semua titik pengujian (penempatan kamera) perokok terdeteksi wajah oleh Webcam. Berdasarkan hasil tabel pengujian di atas terlihat bahwa keakuratan sistem dalam mendeteksi perokok pada ruangan tertutup adalah sebagai berikut:

Hasil akurasi dapat dipresentasekan:

$$
\begin{aligned}
& =\frac{\text { Wumlah vitik yang berhasil }}{\text { jumiah tizik keseluruhan }} \cdot 100 \% \\
& =\frac{9}{9} \cdot 100 \% \\
& =100 \%
\end{aligned}
$$

Hasil akurasi dari pengujian yang sudah dilakukan adalah sebesar $100 \%$ sesuai dengan kebutuhan sistem yang diperlukan.

\section{KESIMPULAN}

Berdasarkan hasil perancangan dan implementasi prototipe smart smoker pada kantin fakultas teknik menggunakan sensor MQ7, Webcam, Motor Servo dan Raspberry Pi 3 tipe $\mathrm{B}+$ serta Telegram ini didapat kesimpulan, yaitu:

1. Implementasi yang dilakukan untuk pembuatan alat pendeteksi asap rokok ini sesuai denga perancangan 
fungsionalitas yang telah dirancang sebelumnya, serta berjalan sesuai dengan fungsionalitas.

2. Hasil analisis pada ruangan kelas sangat sempurna hasilnya tanpa ada hembusan angin dari luar karena ruangan tertutup, mengapa demikian karena kelas pada keadaan mati ac karena pengujian di lakukan pada jam pulang kuliah dan posisi ac mati.

\section{REFERENSI}

[1] Peraturan Universitas Udayana Tentang Larangan Merokok di lingkungan Kampus.

[2] Adhi Krisnawan. 2015. "Perancangan Sistem Keamanan Ruangan Menggunakan Raspberry Pi." (Tugas Akhir). Bandung: Universitas Telkom.

[3] S, Bhuvaneswari and Sahaya Anselin Nisha. 2014. "Implementation of TCP/IP on Embedded Webserver Using Raspberry Pi In Industrial Application". International Journal of Advanced Research in Computer and Communication Engineering Vol. 3.

[4] Sibaranin, Marimbun. 2008. "Implementasi Sistem Wireless Sensor Network Berbasis Internet Protocol (IP) Untuk Pemantauan Tingkat Polusi Udara". Universitas Indonesia Depok.

[5] Ragil Febrio Giant, Darjat, Sudjadi. 2015. "Perancangan Aplikasi Pemantau Dan Pengendali Piranti Elektronik Pada Ruangan Berbasis Web" Semarang: Universitas Diponegoro. [6] Ya'kut,Haris Aydin,Arinto Yudi Ponco. 2014. "Rancangan Bangun Sistem Pengukur Gas Karbon Monoksida (Co) Menggunakan Sensor Mq-7 Berbasis Mikrokontroler Atmega 16a"Kumpulan Jurnal Vol.16

[7] Septian Iswanjaya, M. Julius St., Onny Setyawati .2015. "Indikator Kualitas Udara Berdasarkan KadarGas Karbon Monoksida Menggunakan Menggunakan Sensor Mq-7 Dengan Tampilan Dot Matrix"

[8] Rizki Mardita. 2010. "Sistem Pengendalian Dan Pemantauan Lampu Lalu Lintas Melalui Internet Menggunakan Webcam." Depok: Universitas Gunadarma.

[9] Matt Richardson \& Shawn Wallace. 2012. "Getting Startedqith Raspberry Pi" Sebastopol, California: O'REILLY.

[10] Partner, Kevin. 2014. "Ultimate Guide to Raspberry Pi 2". London: Dennis Publishing Ltd.

[11] SARUNGALlO, Semuel Kete; RAKA AGUNG, I Gusti Putu; JASA, Lie..2016. Majalah Ilmiah Teknologi Elektro,Rancang Bangun Alat Ukur Uji Emisi Gas Karbon Monoksida (CO) Berbasis Mikrokontroler.

[12] Agung, Fajri Septia and Farhan, M. (2013) "Sistem Deteksi Asap Rokok Pada Ruangan Bebas Asap Rokok Dengan Keluaran Suara". STMIK MDP

[13] BUDHANA, I Made Arya; SWAMARDIKA, Ida Bagus Alit; DIVAYANA, Yoga. Rancang Bangun Robot 6WD Dengan Sensor Gas TGS2600 Menggunakan Metode Wall Following Berbasis Arduino Mega 2560. Majalah Ilmiah Teknologi Elektro, [S.1.], v. 17, n. 1, p. 5158 , july 2017. ISSN 2503-2372. 
[Halaman ini sengaja di kosongkan] 